\title{
Yok Olan Bir Tipolojinin Arkeolojisi: Türkiye Coğrafyasında Moteller
}

\author{
Archeology of a Vanishing Typology: Motels in the Geography of Turkey
}

\author{
Gökçeçiçek SAVAŞIR, ${ }^{1}$ ㅇ Zeynep TUNA ULTAV²
}

ÖZ

Bu çalışmanın odağı, günümüz Türkiye coğrafyasında yok olan bir tipoloji olarak karşımıza çıkan motellerdir. Bu odak kapsamında, yüzyıl başında Amerika bağlamında ve yüzyıl ortasında Avrupa'da ortaya çıkan öncülleri üzerinden çerçevesi çizilecek çalışmada, Türkiye turizm mimarlığı kesitindeki motel tipolojisi, yarım yüzyılı aşan tarihçeleriyle mekânsal, ekonomik ve sosyo-kültürel açılardan irdelenecektir. Her iki ölçekte yaşanan dönüşüm süreçleri ve onları doğuran tarihsel koşullar içerisinde yorum ve anlam kaymaları göz önünde bulundurularak, tipolojinin küresel ölçekte geçirdiği dönüşümün Türkiye bağlamındaki izleri aranacaktır. Turizm konaklama yapıları arasında önemli bir yeri olan moteller üzerinden, mimarlık ve turizm alanlarına ait kavram ve niteliklerin açığa çıkarılması için yapılacak olan bu arkeolojide, konum, ölçek, biçim gibi mimari özellikler ile tüketim kültürü içinde motel işletmelerinin popülerliklerini yitirerek yok olmaya yüz tutan dönüşümleri, görsellerle desteklenen literatür taraması yöntemiyle incelenecektir. Kentteki konumu ve küçük ölçeği, biçimsel ve işlevsel yalınlığı ve sunduğu mekansal konfor anlamında özgün bir tipoloji olarak turizm mimarlığı tarihi ve literatüründe karşımıza çıkan motel tipolojisinin, özgün anlamıyla, kullanıcılarına "yeni yaşam biçimi” sunduğunu söylemek mümkündür. Ancak, tarihsel olarak Türkiye'deki örnekler (Emniyet Motel, Florya ve Kilyos Tesisleri bünyesinde yer alan A ve B Moteli, TUSAN Motel zinciri ve Çizmecioğlu Motel dışında) bu tanıma uymamaktadır. Bir başka deyişle, aslında bu tipolojinin Türkiye bağlamında özgün anlamıyla uygulandığından söz etmek güçtür. Motel tipolojisi, kıyı turizmine yapılan vurguyla kıyılara yerleşen bir turizm anlayışıyla anlam değiştirmiş, dolayısıyla Türkiye'de yerel yorumunu bulmuştur.

Anahtar sözcükler: Motel; motel mimarlığı; motel tarihçesi; tipoloji; turizm mimarlığı; Türkiye'de motel.

\section{ABSTRACT}

Encountered as a vanishing typology in Turkey's geography, motels are the focus of this study. In this context, Establishing a framework from the precedents that arouse in the American context at the beginning of the twentieth century and European context in midcentury, the motel typology in tourism architecture in Turkey was analyzed in spatial, economic and socio-cultural aspects with their history over half a century. This study attempted to sought the traces of the transformation that this typology went through in a global context considering transformation processes and semantic shifts within the historical context that generates them. In this study conducted to reveal the concepts and qualities related to the realms of architecture and tourism through motels having a significant place among tourism accommodation, the architectural features of motels such as location, scale and form and the transformations of motel enterprises that have lost their popularity within consumption culture were examined through literature review supported with visuals. It is possible to state that motel typology as a unique typology in terms of its location in the city and its small scale as well as its formal and functional simplicity and its spatial comfort, offers its users "a new way of life" through its original meaning. However, the historical examples in Turkey (except for Emniyet Motel, Florya and Kilyos Establishment A and B Motels, TUSAN Motel chain and Çizmecioğlu Motel) do not fit this definition. To put it more precisely, it is difficult to see the implementation of motel typology in its original sense in the context of Turkey. The meaning of Motel typology has changed in parallel with a shift in tourism understanding focusing on coastal settling and has found its local interpretation in Turkey.

Keywords: Motel; motel architecture; motel history; typology; tourism architecture; motels in Turkey.

'Dokuz Eylül Üniversitesi Mimarlık Fakültesi, Mimarlık Bölümü, İzmir

${ }^{2}$ Yaşar Üniversitesi Mimarlık Fakültesi, İç Mimarlık ve Çevre Tasarımı Bölümü, İzmir

Başvuru tarihi: 20 Kasım 2018 - Kabul tarihi: 27 Şubat 2020

İletişim: Zeynep TUNA ULTAV. e-posta: zeynep.tunaultav@yasar.edu.tr 


\section{Giriş}

Tip, "aynı cinsten bütün varlıkların veya nesnelerin temel özelliklerini büyük ölçüde kendinde toplayan örnek" olarak tanımlanmaktadır. ${ }^{1}$ Mimarlıkta ise tip; biçimsel, işlevsel, strüktürel olarak benzer yapıt-çevre ilişkilerine ve çevre tekniklerini kullanma biçimlerine sahip, bir yapı ile karakterize edilen ve bir grup nesneyi/bilgiyi tanımlayan bir kavrama ya da özgün olguyu ve özü belirleyen sınıflandırma sistemine işaret etmektedir. ${ }^{2}$ Mimarlıkta tipoloji (tip bilimi) ise, bir yandan kişisel yaratıcılıkla dönüşmeyi bekleyen imgelem deposu olarak mimari üretim sürecinde kuramsal bir araç; öte yandan morfolojik sınıflandırmalarda doğal yapısal benzerlikleri ve farklılıkları anlamak için işlevsel bir araçtır. ${ }^{3}$

Büyük kentlerde ya da daha küçük yörelerde yer alabilen otel, yoğun kullanımıyla konaklama yapıları arasındaki en klasik tipolojiyi oluşturur. Oteller, işlevleri gereği verdikleri konaklama hizmetinin yanı sıra sundukları eğlence ve rekreasyon gibi yan hizmetlerle konumlandıkları yerin sosyal hayatına da önemli katkıda bulunurlar. Bir başka konaklama yapı tipolojisi olan motel, ilk örneği 1920'li yılların ortasında Amerika Birleşik Devletleri'nde olarak ortaya çıkarak 1950'lerden itibaren, dünya genelinde ve Türkiye'deki karayollarının gelişimine ve otomobil kullanımındaki artışa koşut olarak gelişmeye başlamıştir. "Motor" ve "hotel" kelimelerinden türetilen "motel", literatürde motorlu taşıtlarla yolculuk edenlerin barınmalarını, arabalarını park etmelerini ve başka gereksinimlerini karşılamak için işlek karayolları üzerinde yapılmış yapı ya da yapı grubundan oluşan otel olarak kullanılır. Geçtiğimiz yüzyılda konaklama endüstrisinin önemli bir parçasını oluşturan bu yeni tipoloji, genellikle işlek karayolu ağı üzerinde konumlanan; motorlu taşıtlarla uzun süre seyahat edenlerin araçlarını park etme, barınma, yeme içme vb. gereksinimlerini karşılayan konaklama tesislerine işaret eder. ${ }^{4}$

Bu çalışmanın odağı, günümüz Türkiye coğrafyasında yok olan bir tipoloji olarak karşımıza çıkan motellerdir. Bu odak kapsamında, yüzyıl başında Amerika bağlamında ve yüzyıl ortasında Avrupa'da ortaya çıkan öncülleri üzerinden çerçevesi çizilecek çalışmada, Türkiye turizm mimarlığı kesitindeki motel tipolojisi, yarım yüzyılı aşan tarihçeleriyle mekânsal, ekonomik ve sosyo-kültürel açılardan irdelenecektir. Her iki ölçekte yaşanan dönüşüm süreçleri ve onları doğuran tarihsel koşullar içerisinde yorum ve anlam kaymaları göz önünde bulundurularak, tipolojinin küresel ölçekte geçirdiği dönüşümün Türkiye bağlamındaki izleri aranacaktır. Turizm konaklama yapıları arasında önemli bir yeri olan moteller üzerinden, mimarlık ve turizm alanlarına ait kavram ve niteliklerin açığa çıkarılması için yapılacak olan bu arkeolojide, konum, ölçek, biçim gibi mimari

\footnotetext{
http://www.tdk.gov.tr

Bandini, 1984, s. 73-82.

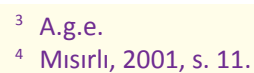

özellikler ile tüketim kültürü içinde motel işletmelerinin popülerliklerini yitirerek yok olmaya yüz tutan dönüşümleri, görsellerle desteklenen literatür taraması yöntemiyle incelenecektir.

\section{Turizm Mimarlığında Motel Tipolojisinin Ortaya Çıkışı ve Mimari Özellikleri}

20. yüzyıl başında refahın bir göstergesi olan seyahat etme pratiği, endüstri toplumunda iş̧̧i sınıfina göre daha çok gelire ve boş zamana sahip orta sınıfin yanı sıra teknik ve mekanik yeniliklerle ortaya çıkan yeni dinlence ve rekreasyon olasılıklarıyla dönüşmüştür. ${ }^{5}$ Mobil turizm ve motellerin tarihinde ayrıcalıklı bir yere sahip olan Amerika kıtasında seyahat güzergâhlarını biçimlendiren demiryollarından sonra, 20. yüzyıl başında eyaletler arası açılan yeni otoyol ağı, araç ulaşım güzergâhlarını ve güzergâh peyzajlarını da belirlemiştir. Henry Ford'un 1908'de Model $T$ olarak adlandırdığı ilk seri üretim otomobillerle birlikte, karayolu seyahati hızla artmış; kent yaşamı, planlaması ve mimarisinin ayrılmaz bir parçası haline gelmiştir.

Öte yandan, "1920'ler ve 1930 'larda, seyahat endüstrisinde Amerika'dan doğan yeni bir seyahat tarzı gelişmiş; otomobille seyahat etmenin getirdiği mekânsal esneklik, Amerikalıları tatillerini tatil köyü, plaj oteli ya da kamp alanı gibi tek bir yerde değil, bir eyalet, bir coğrafi bölgede ya da tüm ülke çapında seyahat etmeleri için teşvik etmiştir." Uzun mesafeli otomobil seyahatlerinin turizm endüstrisindeki etkileri, araç-kampları (auto-camping), çadırlı yol üstü kamusal ve özel mülkiyetli kamp alanları (municipal and private camps), kabin/kulübeli (cabin) kamplar, kabin avluları (cabin court) gibi farklı konaklama biçimleri olarak özetlenebilir. Otomobille seyahat, mevcudun "demokratik, hızlı, verimli ve ucuz" bir alternatifi olarak yüceltilmiş, yeni orta ve üst sınıf turistler için "özgürlük ve zevkin çekici kaynağı" olarak tanıtılarak popülerliği artmıştr.. ${ }^{7}$ Gitgide yaygın bir tüketim malzemesine dönüşen otomobil ile mobil turizm gelişmiştir. Diğer yandan, evlerinden uzakta seyahat edenler ve araçları için kolay erişilebilir ve kent dışı karayolları üzerinde ev konforunda konaklama hizmeti verebilen moteller ortaya çıkmıştr. Otomobil kültürünün turizm mimarlı̆̆ına yansıması olarak değerlendirilebilecek motel tipolojisinin ilk nüvesi, Arthur S. Heineman'ın otomobille Güney Kaliforniya'da yaptı̆ı seyahatler sırasında ortaya çıkmıştır. Yolculuk süresi dönemin koşullarında otomobille iki gün süren Los Angeles-San Francisco karayolu üzerinde, San Luis Obispo'da konumlanan Milestone Mo-Tel, gün boyunca yapılan yolculuğun ardından bir konaklama durağı

Davis, 1992, s. 361.

6 Kopper, 2013, s. 781.

1900'de kurulmuş olan Güney Kaliforniya Otomobil Kulübü (The Automobile Club of Southern California) 1906 'da yol haritaları, 1917 'de ise otel rehberleri basmaya başlayarak oldukça önemli rol oynamıştır. Automobile Club of Southern California Collection, 1892-1963, (http:// digitallibrary.usc.edu/cdm/landingpage/collection/p15799coll59). 


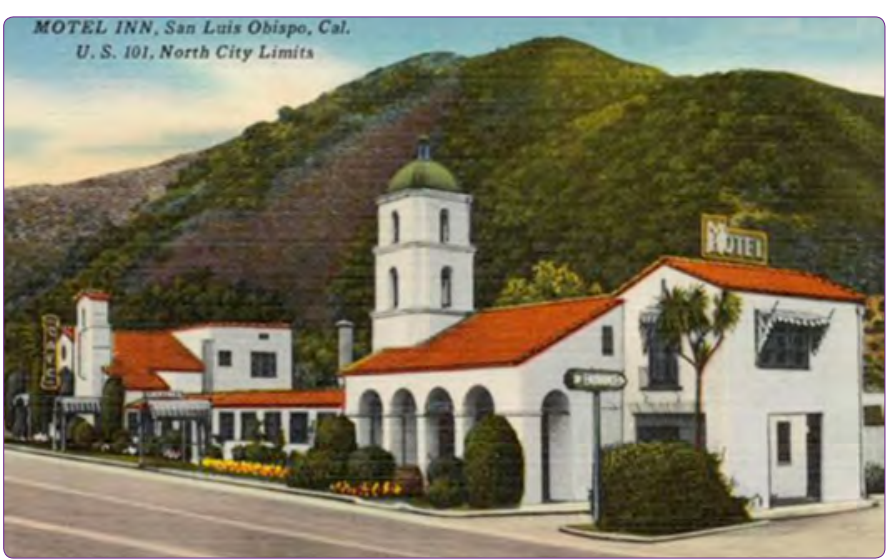

Şekil 1. Motel Inn, kartpostal (Yazarların arşivi, 2017)

oluşturmak amacıyla 1925 yılında açılmış ilk moteldir; Motel Inn adıyla 1991 yılına kadar hizmet vermiştir (Şekil 1). ${ }^{8}$ "Motor" ve "otel" sözcüklerinden türetilen motel ${ }^{9}$ sözcügü, kullanımının yaygınlaşmasıyla, "motorlu taşıtlarla yolculuk edenlerin barınmalarını, arabalarını park etmelerini ve başka gereksinimlerini karşılamak için işlek karayolları üzerinde yapılmış otel" tanımıyla sözlüklere girmiştir. ${ }^{10}$

Rasyonel, işlevsel, sade ve ucuz bir seyahati destekleyen yeni bir yapı tipolojisi olan motel, ${ }^{11}$ merkezî bir avlu etrafinda yerleştirilmiş kabin/kulübeler yerine, Amerikan orta sınıfinın konutları olarak ortaya çıkan banliyö bungalovlarının yine bir merkezî avlu etrafinda bir araya getirilmesiyle ortaya çıkmıştr. ${ }^{12}$ Motellerin ilk örnekleri, mimari açıdan bölge yaşam tarzına ve iklimine uyumlu, bahçe içinde, tek ya da az katlı, açık plana sahip, geniş saçaklı ve sundurmalı, inşaat açısından ucuz, temelsiz, pratik, basit, özellikle tekil aileler için ideal bir konaklama çözümü olan banliyö bungalovlarını anımsatmaktadır. Moteller, demiryolu üzerinde konumlanan lüks otellerden ve çoğunlukla erkek müşterilerin kaldığı kent içi iş otellerinden; konumları, sundukları park ve servis olanaklarıyla farklılaşmıştır. Sıcak-soğuk su tesisatlı, telefonlu modern bir banyo ve özel tasarlanmış mobilyalara sahip standart odalardan, deluxe oturma odaIı dairelere çeşitlilik gösteren konaklama birimlerinin her birine ait tam donanımlı araç park yerleri, ortak mutfak, çamaşırhane, kurutma ve oyun alanları ile desteklenmiştir. Zamanla farklı coğrafyalarda yol üstü konaklamalarına işaret eden daha jenerik bir terime ve otomobil çağının yeni mimarisinde yeni bir yapı tipolojisine dönüşmüştür. ${ }^{13}$

\footnotetext{
Heineman, ilk moteli inşa ettirdiğinde, yapının üzerinde yer alan tabelada otel kelimesinin yanlışlıkla 'motel' olarak yazıldığı yönünde halktan aldığı uyarılar nedeniyle, toplumun henüz bu terim için hazır olmadığına karar vermiş; sözcüğü 'Mo-Tel' şeklinde çizgiyle kullanmaya başlanmıştır (Roth, 2000, s. 16; Elston, 1998, s. 5).

$10 \mathrm{http}: / /$ www.tdk.gov.tr.

${ }^{11}$ Karayolundan izole edilmiş $U$ ya da
}

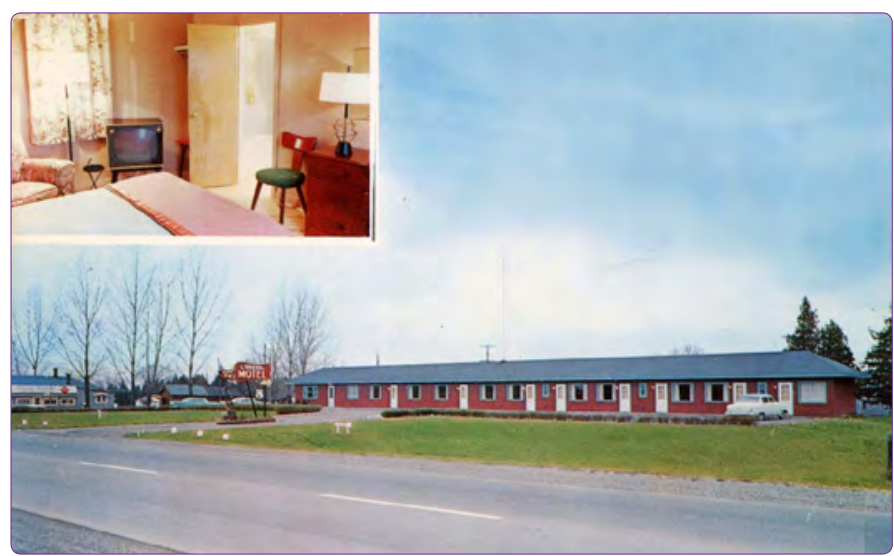

Şekil 2. Karayolu üzerinde konumlanan motellerden biri olarak Original Motel, Ontario ("SwellMap" Arşivi, https://www.flickr.com/photos).

Moteli tanımı gereği otelden ayrıştıran en önemli tipolojik özellikler; kentle ve karayoluyla ilişkisi bağlamında konum, otele kıyasla daha küçük olan ölçek ve daha düşük olan konfor, işlevsellik ve biçimsel yalınlıktır. Illk moteller, tren istasyonlarının ve ticaret merkezlerinin yakınlarında yer alan otellerden konumları itibariyle ayrışmıs ve doğal çevrenin ve yöresel özelliklerin daha belirgin olduğu kent dışı/kırsal alanlardan geçen karayolları üzerinde konumlanmıştır (Şekil 2). Plan şemalarında lobi, ofis, büfe, yemek salonu gibi, seyahat edenlere hizmet sunan birimler karayoluna yakın bir şekilde çözülmüş; böylece karayolunun trafik ve gürültüsü yalıtılmıştır. Konaklama birimlerinin açık araç park yeriyle kurdukları dolaysız ve kolay erişilebilirlikleri, motelleri yol üzerinde konumlanan diğer turizm yapıları/ yapı gruplarından ayırır ve bu, seyahat eden konuklara sunulan en önemli konforlardandır. Konaklama birimlerinin ön ve arka kapıları, doğal havalandırma ve yangın güvenliği sağlar. Otellere göre daha küçük işletmeler olan moteller, otellerde olduğu gibi ticari kaygı güden resmî lobilere, yemek ve balo salonları gibi karmaşık sosyal/davranışsal beklentileri de içeren resmî mekânlara sahip değildir. Aksine, motellerde uzun yolculuk sonrası sosyalleşme amacına hizmet eden kamusal mekânlarla birlikte işletme sahibi ve personelin misafirperver, dostça tavrı ön plandadır. Otel tipolojisine kıyasla küçük ölçekli ve düşük konforlu olmaları, bazı ülkelerdeki motelleri tanımlayan en belirleyici özellik olarak turizm literatüründe ortaya çıkar. ${ }^{14}$ Sosyal statü göstergesi kabul edilen ve kent otellerinde görülen lüks eşyalar/nadir malzemeler yerine yalın ve işlevsel mekânlar ve mobilyalar görülür (Şekil 3).

1930'larda özellikle Amerika'da daha geniş kitlelerin ulaşabildiği otomobiller, İngiltere, Fransa, Almanya, tüketim kültüründe değişime; seyahatte demokratikleşmeye

\footnotetext{
14 Örneğin Fransa'da moteller, üç kata kadar olan ve tek yıldızlı otele eşdeğer konaklama yapılarıyken, Almanya'da hizmet veren Accor's Hotel Formule 1 gibi bazı Fransız motel zincirleri uygun fiyatlı, küçük, sade, detaysız odalar sunmaktadır (Endy, 2000).
} 

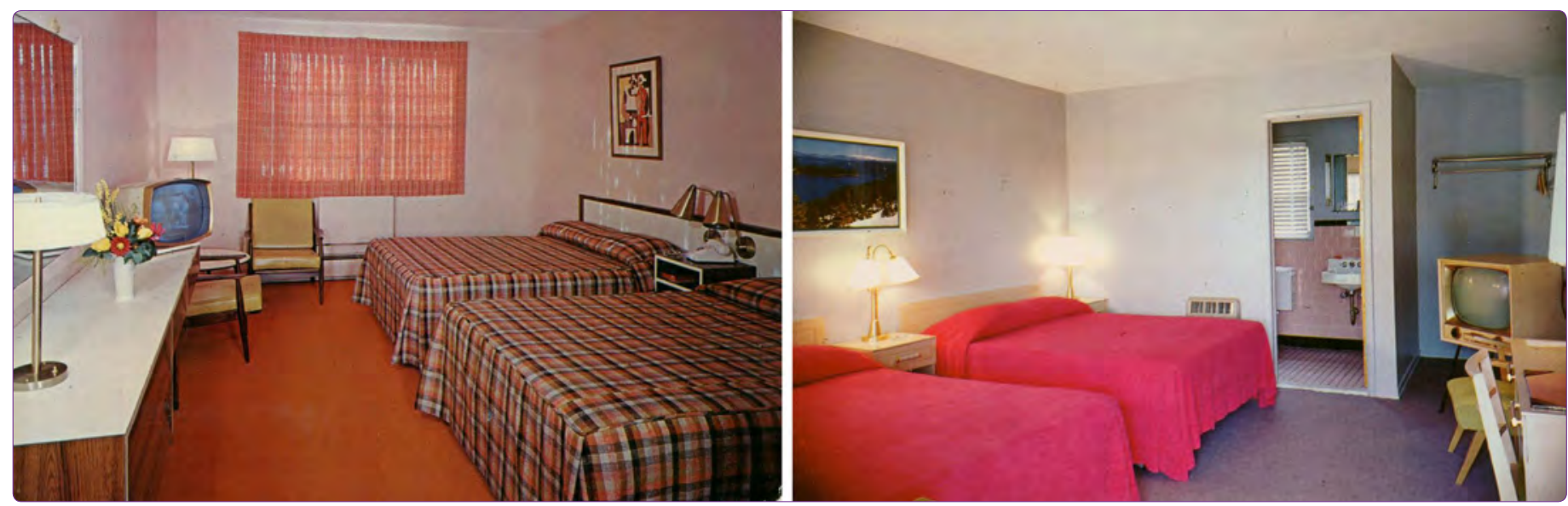

Şekil 3. ABD motel odası iç mekân örnekleri; solda Stadium Motor Lodge, New York, sağda Chadwick Motel-New York ("SwellMap" Arşivi, https:// www.flickr.com/photos).

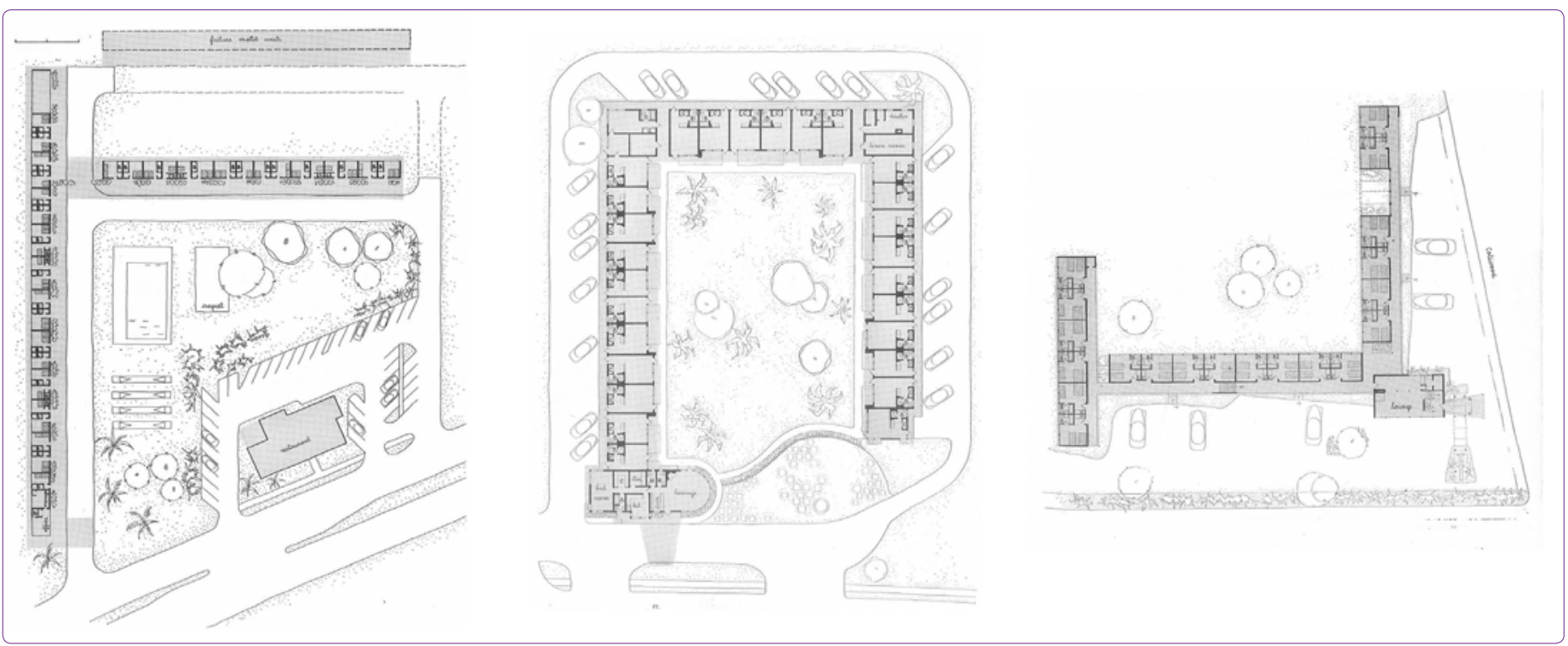

Şekil 4. ABD motel vaziyet plan örnekleri, 1950'ler (Baker, Funaro, 1950).

ve özgürleşmeye yol açmıştir. Konaklama birimlerinin tüm kapı ve pencerelerin dıştaki yaya yoluna açıldığı bu moteller, 1940'lardan itibaren yeni teknoloji ve hizmetlerle güncellenmiş, standart odalara klima, televizyon gibi teknik donanım eklenmiştir. ${ }^{15}$ Erken dönem küçük, yerel aile işletmesi (mom-and-pop) motellerin mevcut restoran ve benzin istasyonuna daha büyük ortak mekânlar da eklenmiştir. Rasyonel ve işlevsel ilk motel örneklerinde, minimum gereksinimlere, lüks olmayan ve optimum çözümlerle karşılık verilmiştir. İkinci Dünya Savaşı sonrasında otomobil en temel ulaşım biçimi haline gelirken moteller de, otoyol kavşaklarına yakın bir şekilde konumlanarak günümüzde kullandığımız anlamdaki motele dönüşmüştür. Bu etkiler, 1950'lerden itibaren küresel ölçekte de hissedilmiş; karayollarının gelişimiyle motellerin sayıları ve kaliteleri de artmıştır. ${ }^{16}$

\footnotetext{
${ }^{15}$ Elston, 1998, s. 13-16.
}

\footnotetext{
${ }^{16}$ Elston, 1998; Endy, 2000.
}

\section{Motel Tipolojisinin Yükselişi}

1950'lerde akaryakıt üretim ve tüketim dengelerine odaklı küresel ölçekli enerji ve ekonomi politikaları ile ulaşım alanındaki teknolojik gelişmeler, otomobille seyahati ve karayollarını ulusal/uluslararası bağlamlarda birincil ve yaygın hale getirmiş; Avrupa'da da kitlesel turizmin gelişmesine neden olmuştur. "Standartlaşmış ürünlere ve hızlı ciroya dayanan, ucuz fiyatlara izin veren ve çok sayıda bireysel tüketiciye hitap eden Fordist kültürel üretim" ile 1920 'lerden itibaren özel otomobillerinde tatile giden Amerikalı turistleri 1950 'lerden sonra, makul fiyatla belli bir standartta konaklayabilecekleri motellere yöneltmiştir (Şekil 4-6). ${ }^{17} 1960$ 'larda otomobille seyahatin daha da popülerleşmesiyle, motellerin önemi hemen hemen her ülkede gittikçe artmış; turistler için planlanan geniş seya-

\footnotetext{
${ }^{17}$ Nathaus, 2013, s. 743.
} 


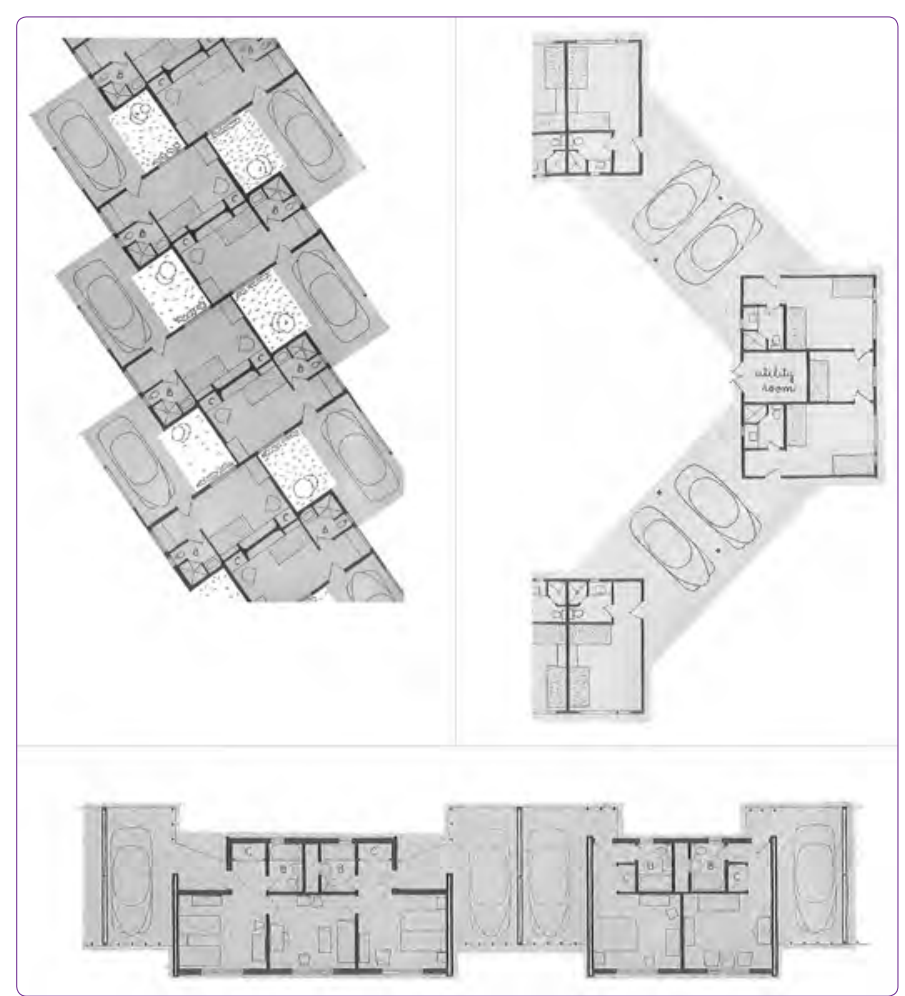

Şekil 5. ABD motel plan şeması örnekleri, 1950'ler (Baker, Funaro, 1950).

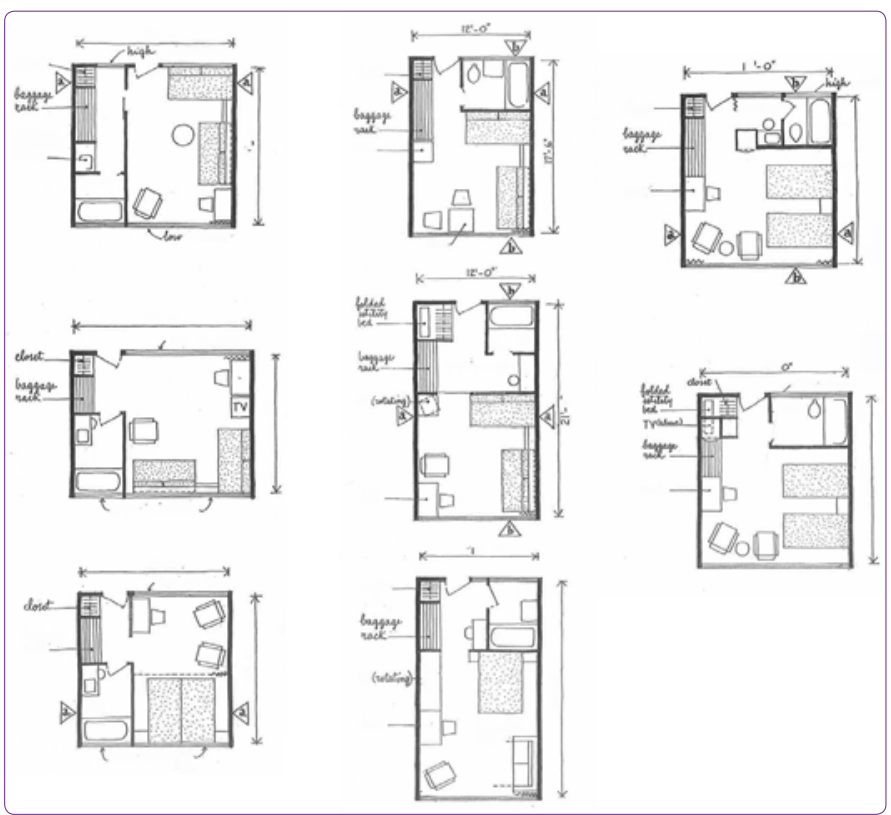

Şekil 6. ABD motel plan iç organizasyonuna örnekler, 1950'ler (Baker, Funaro, 1950).

hat programlarına hizmet verebilecek pek çok motel inşa edilmiştir. ${ }^{18}$ iki ya da üç katlı yapılarda, odaların servis çekirdeklerinin merkezde toplanmasıyla lineer bir düzende tasarlandığı görülür (Şekil 7). Bu yılların restoran ve kokteyl

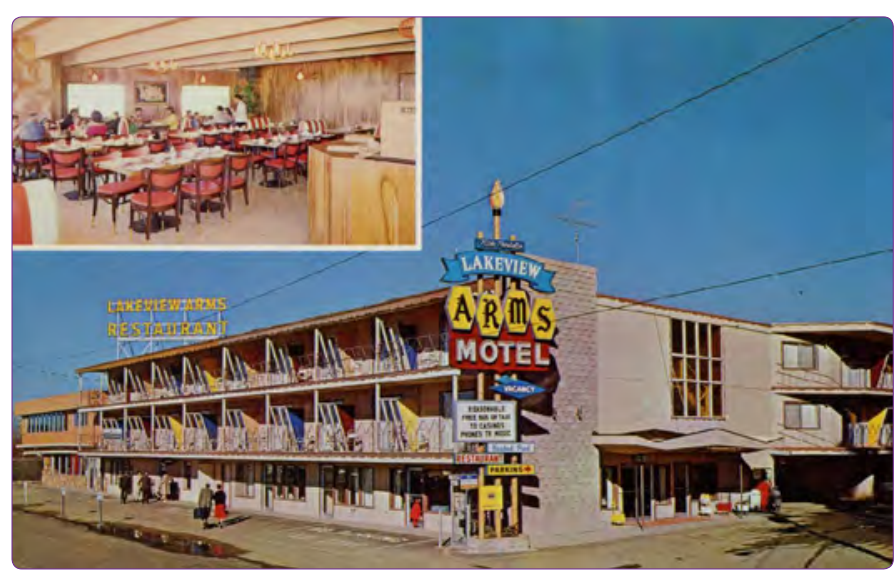

Şekil 7. Lineer düzenlenmiş odalarıyla otelleri anımsatan moteller, Lake View Arms Motel, California ("SwellMap" Arşivi, https://www. flickr.com/photos).

salonuna da sahip motellerinde, basit geometrik formlu modüler odalarında, banyolara mermer armatürler ve saç kurutma makinaları eklenmiştir. Öte yandan, tren istasyonları yakınında ya da kent içinde inşa edilen otellere de park yeri, hızlı giriş-çıkış hizmetleri ve daha düşük konaklama ücretleri gibi özellikler eklenmiştir. Böylelikle, motellerle otelleri ayrışan özellikler kaybolmuş; iki farklı tipoloji birbirine benzemeye başlamıştır. ${ }^{19}$

Motellerin sayılarının hızlı artışında kentin gelişimi, tatile harcanan zaman ve paranın ve otomobil kullanımındaki arţ̧̧ etkili olmuştur. Bu dönemde Amerika'da kent içi gecelik konaklama biçimlerine alternatif olarak görülmeye başlanan moteller, eyaletler arası otoyol bağlantılarına yakın konumlarda tek ya da iki katlı inşa edilerek otomobil odaklı yaşam biçimlerine cevap veren, kent içi otellerle kıyaslandığında tatilcilerin odalarına eşyalarını kendilerinin taşıdığı daha serbest ve yaygın tercih edilen bir konaklama biçimine dönüşmüştür. Konukları, karayolunda seyahat edenlerden tatilcilere evrilen bu yeni tip motellerde, çift yataklı, televizyon setli, telefonlu ve klimalı daha geniş odalar ile yemek salonu, lobi, hediyelik eşya dükkânı, yüzme havuzu gibi popüler hizmetleri de eklenmiştir. ${ }^{20}$ Zamanla konumları karayolu üzerinden farklı Amerikan sahillerine kayan moteller ile işletme açısından sektöre farklı bir boyut açma potansiyeliyle kurulan motel zincirlerinin (Şekil 8) yeni ve lüks yapıları, tipolojik olarak motel ve otel arasındaki ayrımın bulanıklaşmasına neden olmuştur. ${ }^{21}$

Karayoluyla seyahat eden turist sayısını ve turizm hareketini artırma hedefiyle ortaya çıkan motel olgusu, genellikle büyük petrol şirketlerine ait benzin istasyonlarıyla birlikte tasarlandıkları düşünüldüğünde, motellerin Amerika odakI kapitalist sistem içinde petrol tüketimini artırmadaki rolleri ile birlikte değerlendirilmelidir. Amerika'nın 1952-1969 arasında gözettiği Soğuk Savaş ideolojisi, dönemin tüketim

\footnotetext{
${ }^{18}$ Lockyer ve Roberts, 2009, s. 24.
}

\footnotetext{
${ }^{19}$ Elston, 1998, s. 16-17. $\quad{ }^{20}$ A.g.e. $\quad{ }^{21}$ Elston, 1998, s. 8-9.
} 


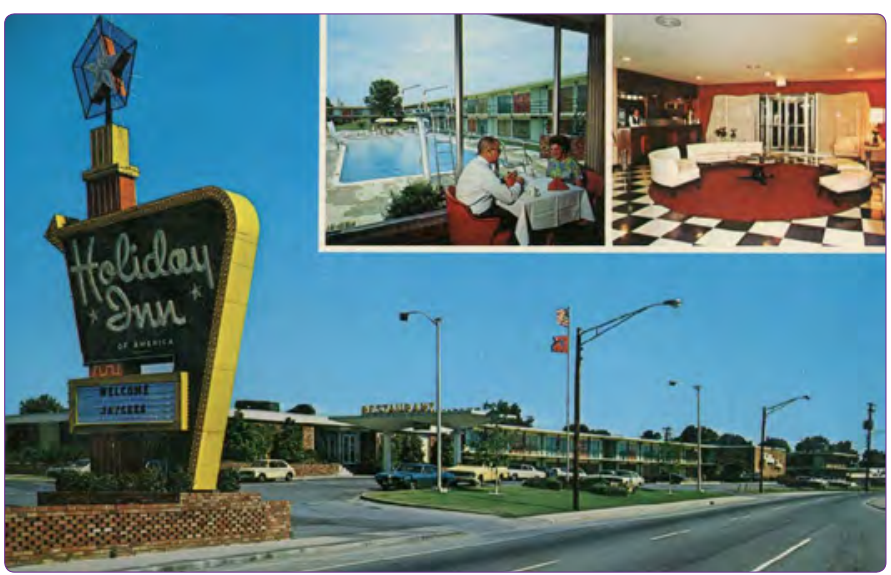

Şekil 8. Holiday Inn Motel Zinciri, Holiday Inn, Tennessee ("SwellMap" Arşivi, https://www.flickr.com/photos).

kültürüne paralel olarak kitle turizmine verdiği önemle de çakışmaktadır. Bu da motellerin Amerika'nın yanı sıra Avrupa ve Akdeniz ülkelerinde de artmasına neden olmuştur. Özellikle büyük petrol şirketlerine sahip Amerika, İngiltere, Fransa gibi ülkelerdeki devinim ve otomobil vurgusu, bu konjonktüre paralel olarak gelişen mimari söylemlerde de yerini bulmuştur. ${ }^{22}$

1950 'lerde Amerika'da oluşan bu yeni seyahat tipi, farklı ülkelerde 1930 lardan itibaren ve özellikle 1950 'lerde inşa edilmeye başlayan hızlı ve modern otoyol ağları ile kitle turizmi çerçevesinde Avrupa'da da görülmeye başlasa da, ${ }^{23}$ bu coğrafyada hiçbir zaman aynı öneme sahip olamamıştr. Konfor ve hizmet açısından Amerika'daki motellerin gerisinden gelen Avrupa örneklerinde, motelin, diğer konaklama biçimlerinden ve otellerden ayıran özelliklerden sadece konuma sadık kalınarak geliştirilen otel zincirleri olarak yorumlandığı görülür. ${ }^{24}$ Örneğin; "1970'lerden itibaren, Fransız zinciri Novotel gibi bazı Avrupalı otel şirketleri, ABD'nin bina otellerini otoyol çıkışlarına ve kavşaklara yakın olarak kopyalamış" ${ }^{25}$ ve Avrupa'daki motellerin biçimsel ve işlevsel olarak motel-otel arası melezlenmesine neden olmuştur. Bu dönemde, Fordizmin turizm endüstrisinde bulduğu karşlıklar olarak görülen düşük işgücü girdisi, zincirlerle optimize edilmiş hizmet üretimi ve odalarda verilen hizmetteki standartları, orta fiyatlı Avrupa otellerinde düzenli olarak görülmezken Amerikan motellerinde ortak bir özellik olarak bulunmaktaydı. Çoğu motel işletme olarak, ülke çapında bir reklam ve rezervasyon sisteminin parçası olan bir zincir içinde, belli yönetim ve hizmet standartlarına uymak durumunda olarak hizmet vermekteydi. Holiday Inn gibi zincirlerde, otel odaları, mobilyalar, dona-

\footnotetext{
22 Örneğin, 1950’lerin sonunda, İngiliz mimarlar Alison ve Peter Smithson, devinimin çağın belirleyici özelliği olduğunu öne sürmüş; özel otomobili, toplumsal ve fiziksel devinimi sağlayan, toplumu bir arada tutan

Cavlović, 2018.

A.g.e., s. 782
}

nım ve olanakların yanı sıra kurumsal tasarım öğelerinin kullanımı için özel standartlar belirlenmiş; hatta motel yapılarının planları bile bir standardizasyon sürecine girmiştir. İşletmeciler bu süreçte, bağlı oldukları şirketin onayı ve mimarların/tasarımcıların rehberlik desteğini almıştır. ${ }^{26}$

Motel tipolojisinin gelişimine, Türkiye bağlamında bakıldığında ise, özellikle 1940'ların sonundaki Marshall Yardımları ve 1950 'lerin başında iktidara gelen Demokrat Parti'nin politikaları çerçevesinde ülke çapında gelişen karayolları ağı ile daha çok kişinin -tercihen özel otomobilleriyle- seyahat etmesinin teşvik edildiği söylenebilir. 1950'li yıllarda, Karayolları Genel Müdürlüğünün kurulması (1950); Turizm Müesseselerini Teşvik Kanununun hazırlanması (24.03.1950) ve yayınlanması (22.05.1953); Turizm Bankasının kurulması (1955) ve Ford Otosan firmasının kurulması (1959), turizm politikalarının da benzer güzergâhta ilerlediğinin göstergeleri olarak kabul edilebilir. ${ }^{27}$ Bu politikalar doğrultusunda, özellikle 1950 'lerin ikinci yarısında Amerikan otomobil endüstrisindeki gelişmelerin küresel ölçekteki yansımaları Türkiye turizm sektöründe de etkisini göstermiştir. Ekonomik kalkınma açısından önemli olduğu görülmeye başlanan turizm alanında, oteller ve tatil köylerinin yanı sıra motellerin de açılması için çeşitli raporlar da hazırlanarak yasal düzenlemelere gidilmiştir. ${ }^{28}$ Turizmde devlet eliyle yatırımlar yapılmış; özel girişimler desteklenmiş ve yaygınlaştrılmıştır: "1950 sonrası uygulanan liberal politikalarla, turizmin bir kalkınma sektörü olarak ele alınması ile Amerikanvari büyük kütleli otel yapıları yaygın uygulama alanı bulurken; dönemin sonunda, yine bir Amerikan kültür ürünü olan moteller, özellikle önemli turizm merkezleri yakınında uygulama alanları bulmuş; (...) bu da kıyılarımızda önemli bir yatak kapasitesi artışına neden olmuştur. Bu yeni yapı türü ile birlikte büyük kent otelleri ile tatil yörelerinde uygulanan konaklama yapıları arasında önemli bir biçimsel ayrım başlatılmış olur." ${ }^{29}$

Amerika kökenli motel tipolojisinin İkinci Dünya Savaşı sonrası dönemde Türkiye'de benimsenen ekonomik kalkınma modelinin ve bu modelin fiziksel altyapısını oluşturmak üzere yürürlüğe konan karayolu taşımacılığı politikalarının yapılı çevreye bir yansıması olarak değerlendirilebilecek dört erken örnekten bahsedilebilir: Bunlardan ilki, Bolu'nun Aydınlık Çeşme Mevkii'nde Shell benzin firması ile Amerika'da gördüğü motellerden esinlenerek motel kurmaya karar veren Bolulu işadamı Mehmet İnan'ın ortaklığı sonucunda hizmete girmiş olan Emniyet Motel'dir (Şekil 5). ${ }^{30}$ Türkiye'nin şahıs tarafindan açılan ilk moteli olduğu ifade edilen Emniyet Motel, Ankara-İstanbul

\footnotetext{
${ }^{26}$ A.g.e., s. 782 .

27 Tuna Ultav, Savaşır, 2016.

28 Örneğin, 1958 yılında CENTO turizm müşaviri George S. Kovach'ın dünyada sayıları hızla artan motel-

ler üzerine düzenlediği ayrıntılı ra- ${ }^{30}$ Gönlügür, 2014; Sağlam, 1995.

por, ülkemizdeki motellerin açılmasında etkili olmuştur (Aydan Bulca, 1979'dan aktaran Sağlam, 1995, s. 131).

${ }^{29}$ Sağlam, 1995, s. 233
} 


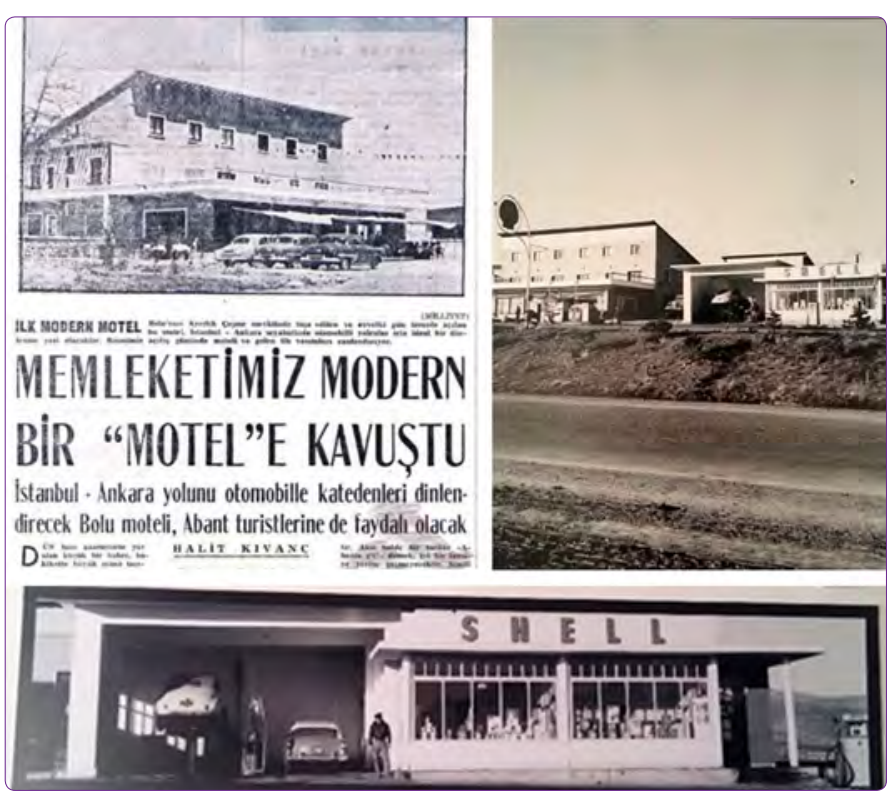

Şekil 9. Emniyet Motel ve yanında yer alan benzin istasyonu (Milliyet gazetesi arşivi, 22.07.1957 ve yazarların arşivi, 2016).

arasında, ulaşım açısından stratejik bir konumda 1957 yılında kurulmuş; zamanın bürokrat ve sivil ileri gelenlerini konuk etmiş̧ir. ${ }^{31}$ Tipolojinin özgün felsefesinden yola çıkarak Türkiye'nin en hareketli karayolu üzerinde konumlanan Emniyet Motel'in kuruluş yıllarındaki fotoğraflarında da hemen yanında yer aldığı görülen Shell benzin istasyonu, motel tipolojisinin özgün niteliğinin korunduğunu göstermektedir (Şekil 9). Emniyet Motel'in açılışının kamuoyu ile paylaşılmasında motel tipolojisinin niteliklerine ilişkin vurgular dikkat çekmektedir. Haberin yazarı, "Türkiye'de ilk modern motelin açıldığını" okuyanların, kendilerine yabancı olan bu tipolojinin "otel" tipolojisinin yanlış yazımı olduğunu düşünebileceklerini belirtmektedir. Haberde, motelin motorlu araçla olan ilişkisine vurgu yapmak üzere, Amerika bağlamı örnek verilerek, “Amerikalı'nın otomobille sinema seyrettiği, otomobille mağazada alışverişe çıktğı, otomobille lokantada karnını doyurduğu gibi", otele de otomobiliyle gittiğinden söz edilmektedir. Ayrıca, gecelik kısa süreli konaklama ya da yol üstünde lokanta olanağı sunan Emniyet Motel'in, oda ve yatak sayısı açısından, kent otellerine göre daha mütevazı olması, 20 odasındaki 41 yatak sayısıyla vurgulanmaktadır. Emniyet Motel'in konumu “istanbul'dan çıkıldıktan $270 \mathrm{~km}$ sonra (takriben 4,5-5 saatte) varılan 'motel' Ankara'ya da 215 km (takriben 2,5-3 saatlik) mesafede" şeklinde tanımlanmakta ve "yolu hemen hemen ortaladığı için İstanbul-Ankara otomobil seyahatini "zahmetsiz hale getirmekte" olduğu belirtilmektedir.

Türkiye'deki öncü motellerden bir diğeri ise, Emniyet Motel'in inşası ile hemen hemen eş zamanlı olarak iss-

${ }^{31}$ Motel, halen aynı ailenin üçüncü nesli tarafindan işletilerek hizmet vermeye devam etmektedir [http://tr.emniyetmotel.com/index.html]. Erişim Tarihi (20.08.2013)

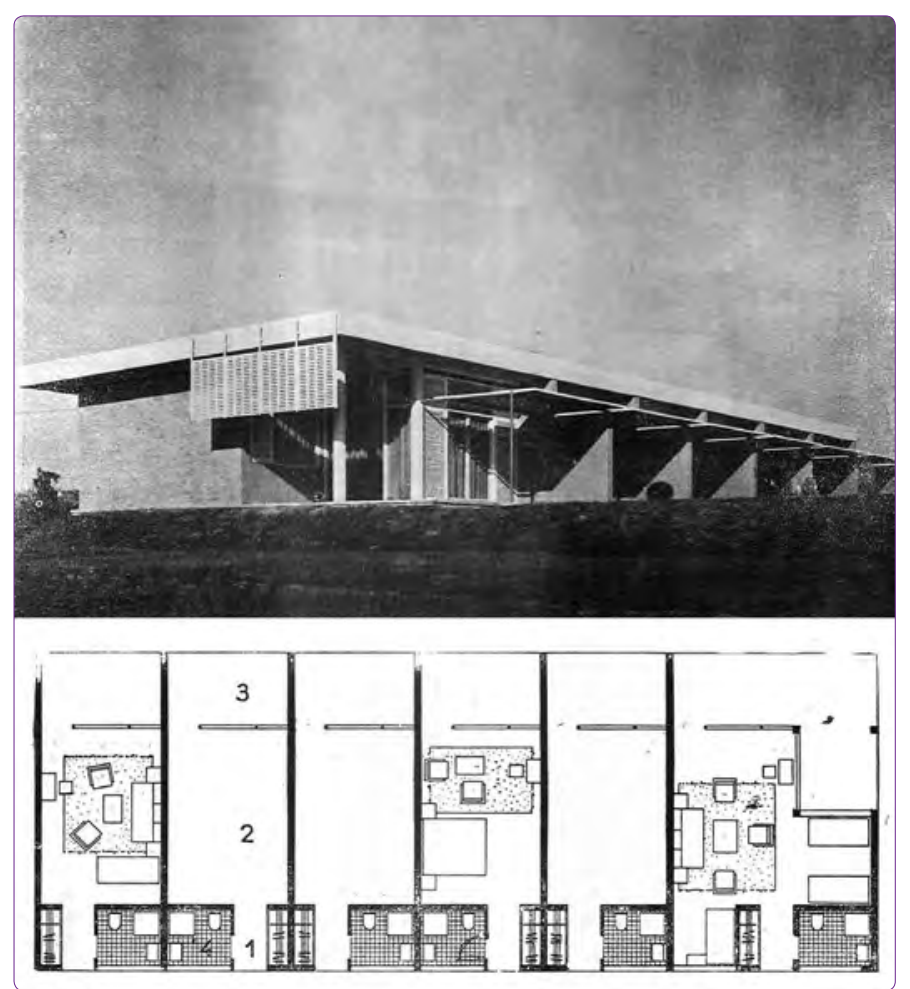

Sekil 10. (Turizm Bankası) Florya ve Kilyos Tesisleri B Moteli; 1950'lerin sonu-1960'ların başı; (üstte) yatak bloğundan görünüş, (altta) B Moteli yatak bloğu plan (1_Giriş, 2_Oda, 3_Teras_4_WC) (Arkitekt, 1961).

tanbul sayfiyesinde inşa edilen Florya ve Kilyos Tesisleri bünyesinde yer alan A ve B Moteli'dir (Şekil 10). Emniyet Motel'den farklı olarak bir devlet kurumu olan ve 1955 yılında kurulan Turizm Bankasının ilk tesisi olarak 1956 yılına tarihlenen bu projenin 1961 yılında Arkitekt dergisinde yayınlandığı görülmekte, ancak yapının inşa yılına ilişkin net bilgive ulaşılamamaktadır. 1956-1961 yılları arasındaki 5 yıllık dönemde inşa edilmiş olduğu düşünülen bu tesisler kapsamında yer alan motellerin, karayolundan uzaklaşarak deniz kıyısında yer almaları ve yanında benzin istasyonu barındırmamaları nedeniyle, tipolojinin özgün özelliğinden farklılaştığı ancak ölçek ve biçimsel özellikleri nedeniyle motel tipolojisinin özelliklerini yakaladığı görülmektedir.

Türkiye'de, 27 Mayıs 1960 intilali sonrasında 1961 Anayasası ile "refah devleti" kavramı benimsenmiş, ülkede sanayileşme başlamış, sosyo-politik ve ekonomik gelişmeler gündemi belirlemiştir. ${ }^{32}$ Devlet Planlama Teşkilatı'nın kurulduğu ve yeni iş kollarının ortaya çıktığı bu dönemde karayolları ve mimari gelişmeye başlamıştır. ${ }^{33}$ Türkiye'de turizmin gelişme aşamaları, ekonomik, politik, sosyal ve yönetsel politika değişimlerine paralel olarak ortaya çıkmıştr. ${ }^{34}$ ilk Türk otomobili Devrim'in (1961), ilk ve tek yerli seri üretimi yapılan otomobil olan Anadol'un (1966) üretilmiş olduğu 1960'lı yıllar için bu kolay, ucuz, çabuk yapılabilen ve bir-iki katlı yeni yapı türü olan motel, Türkiye'de o

\footnotetext{
32 Tekeli, 2007. $\quad{ }^{33}$ Tekeli 2007; Vanlı, $1994 . \quad{ }^{34}$ Nohutçu, 2002
} 


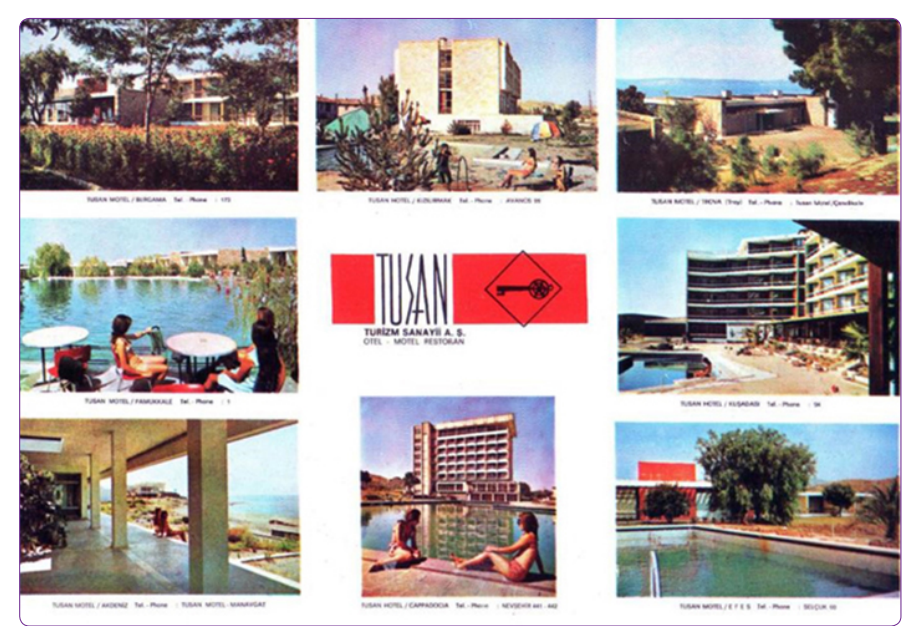

Şekil 11. TUSAN Motel ve Otel zinciri, 1970 'ler; zinciri gösteren kartpostal (Yazarların arşivi).

dönemde hâlâ bilinen bir kavram değildir. Neredeyse hepsi devlet tarafindan ve T.C. Emekli Sandığı için yaptrılan büyük yatırımlar dışında, özel girişimcilerin yaptığı daha küçük ölçekli turizm yatırımlarında, motel gibi yeni tipolojilerin ortaya çıktığı görülmektedir. Bu arayışlardan ilki, Türkiye'nin ilk özel otel-motel zinciri olarak kabul edilen TUSAN M/Otelleri'dir. Çoğunlukla, yabancı turistlere yönelik kültür turizmini başlatmak amacıyla 1960 yılında Yüksek Mühendis Enver Muradoğlu tarafindan kurulan TUSAN (Turizm Sanayi A.Ş.) firması aracılığıyla, aynı mimari yaklaşım içinde projelendirilip inşa edilen Çanakkale, Bergama, Efes ve Pamukkale TUSAN Moteller, 1962 yılında hizmet vermeye başlamıştı (Şekil 11, 12). ${ }^{35}$ Truva, Bergama, Hierapolis, Afrodisyas ve Efes antik kentleri ile Meryem Ana Evi gibi tarihî yerler, bu motellerin yer seçimlerinde önemli rol oynamıştır. 1963 yılında basıımış olan bir TUSAN broşüründe de belirtildiği gibi, "Tüm TUSAN yerleşimleri turistlerin özel araçlarıyla ya da otobüs ile konfor içinde seyahat etmelerine ve rota üzerindeki güzel manzaranın tadını çıkarmalarına imkân verecek bir otoyol ağı üzerinde konumlanmıştr." ${ }^{36}$ TUSAN M/otellerin kuruluş öyküsü kapsamında TUSAN-BP (British Petrol) firması ortaklığının da altnnı çizmek önemlidir (SSekil 13). Emniyet Motel örneğinde olduğu gibi, turistlerin seyahat ettiği otomobil ya da otobüslere akaryakıt, yağlama, yıkama hizmeti sağlamak amacıyla Bergama TUSAN Motel'in yanına benzin istasyonu inşa edilmiştir. TUSAN Moteller 'in otele kıyasla daha

\footnotetext{
35 TUSAN firmasının 1960'ların başında ortay koyduğu proje bir zincir tur projesi olup, farklı zamanlarda açılmış ve/ya hizmet vermiş olan toplamda 11 motel ve oteli kapsamaktadır. Adı geçen 4 motelin dışında kalan motel ve oteller şunlardır: Uludağ Büyük Otel, Erdek TUSAN Otel, Kuşadası TUSAN Otel, Ürgüp TUSAN Otel, Nevşehir TUSAN Otel, Avanos TUSAN Otel, Manavgat TUSAN Motel. Enver
}

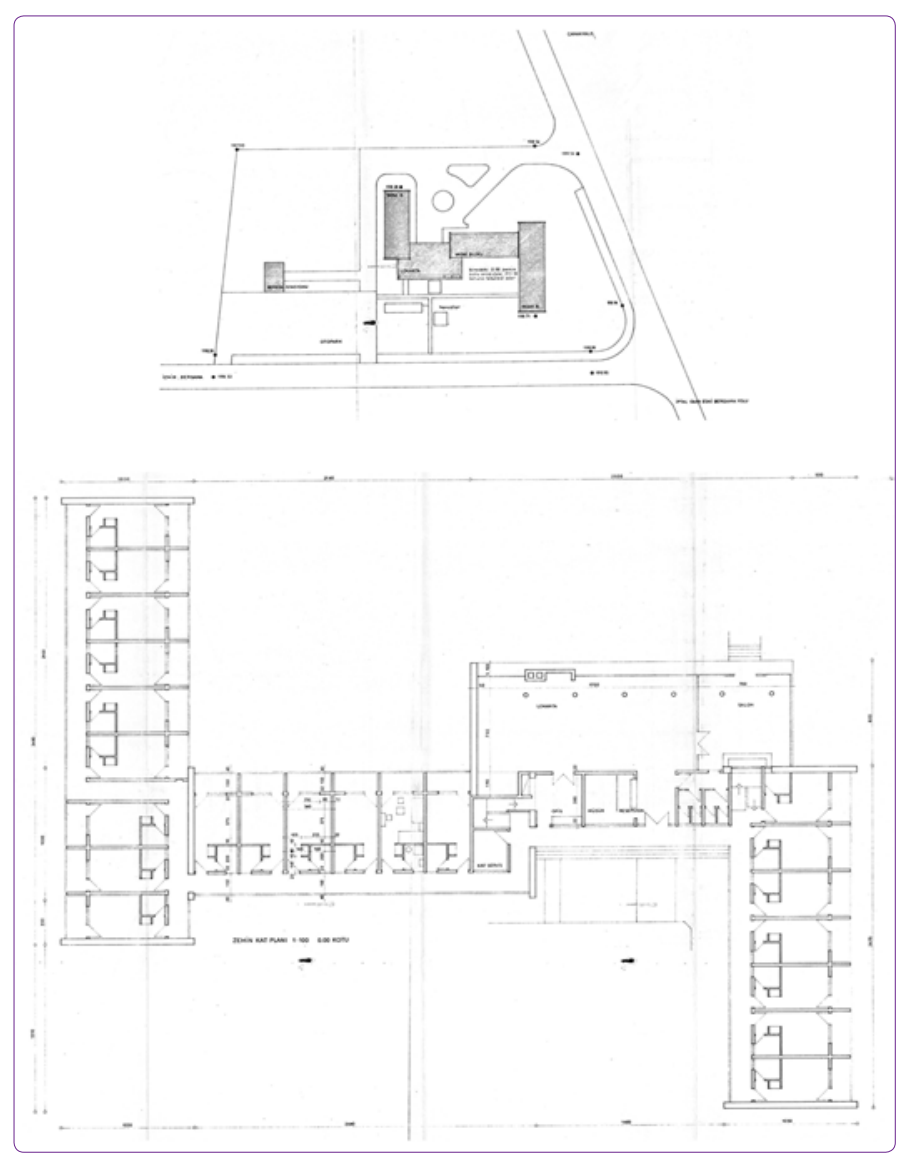

Şekil 12. Bergama TUSAN Motel, vaziyet planı ve zemin kat planı, 1962 (Yazarların arşivi).

küçük ölçekleri ve daha düşük olan konforları, işlevsellik ve biçimsel yalınlıklarıyla motel tipolojisinin Türkiye'deki önemli temsilcileri olduğunu söylemek mümkündür.

Otomobille seyahatin popülerleşmesiyle, 1960 'ların başında, motellerin önemi hemen hemen her ülkede gittikçe artmış; turistler için planlanan geniş seyahat programlarına hizmet verebilecek pek çok motel inşa edilmiştir. Motellerin artan popülerliği, Türkiye'deki mimarlık dergilerinde de moteller hakkındaki yayınlarda kendini göstermektedir. 1961 tarihli "Başka Memleketlerde Moteller" başlıklı yazıda, motellerde göz önünde bulundurulması gereken ilk koşulun, basit, rahat, seyahat sırasında dinlenmek için bütün konfora sahip; aynı zamanda pahalı ve lüks olmadan her bütçeye uygun olmalarıdır. ${ }^{37}$ Öte yandan, her ne kadar o dönemde uluslararası turizm için oldukça revaçta olsa da, motel tipolojisinin Türkiye için hâlâ yabancı bir kavram ve yeni bir olgu olduğu söylenebilir. ${ }^{38}$

Amerika ve Avrupa'daki dönemdaşlarıyla değerlendirilebilecek Türkiye'deki ilk motellerden bir diğeri ise, 1964

\footnotetext{
7 "Başka Memleketlerde Moteller", 1961, s. 69.

38 Türkiye Büyük Millet Meclisi'nde 1960'larda gerçekleşen bir bütçe müzakeresi toplantısında bakanın

konuşmasında "otel, motel" yapacağız ifadesi milletvekilleri tarafindan bir ikileme olarak kullanılıyor sanılarak laubalilik olarak algılanmış ve eleştirilmiştir (Hurda, 2010).
} 


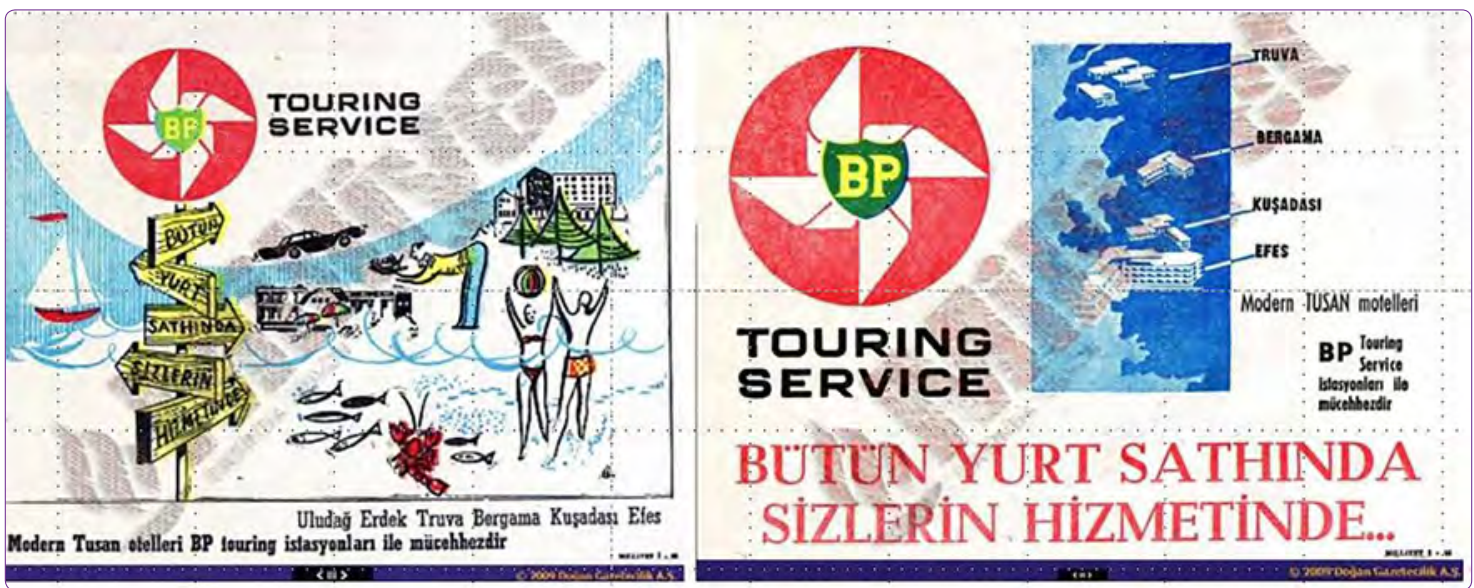

Şekil 13. TUSAN ve BP gazete reklamı, 11.05.1962 ve 18.05.1962 (Milliyet gazetesi arşivi).
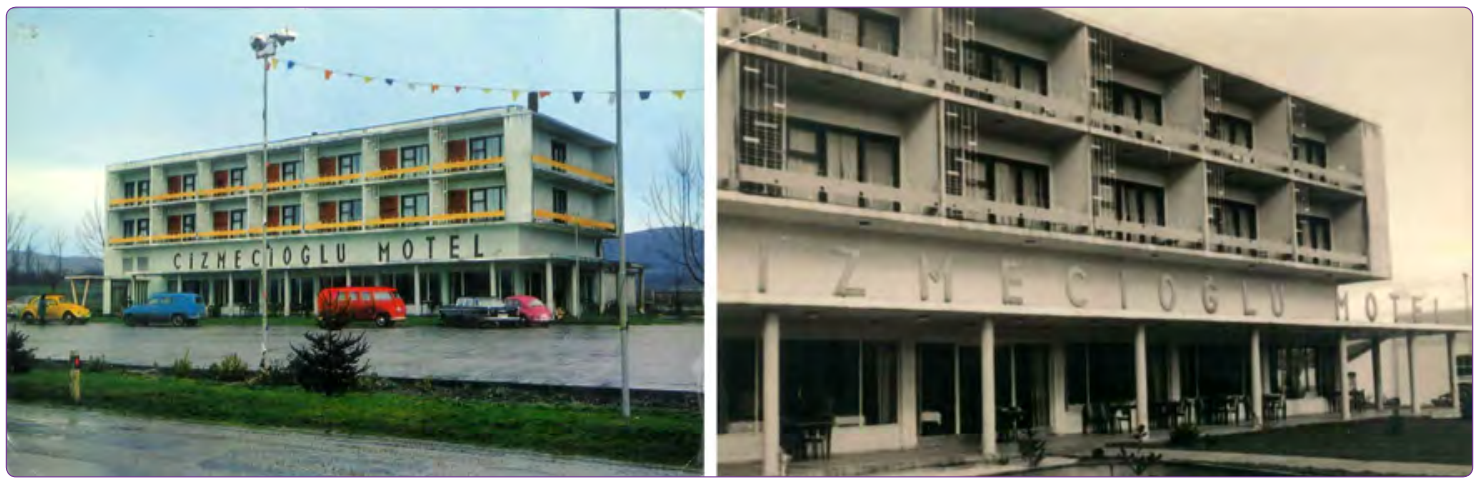

Şekil 14. 1960'larda Çizmecioğlu Motel (Yazarların arşivi 2016).

yılında Bolu'da açılan ve modern bir mimari dile sahip olan Çizmecioğlu Motel'dir (Şekil 14). 1964 yılında Bolulu işadamı Mustafa Kemal Çizmecioğlu tarafindan hizmete açılan Çizmecioğlu Motel, müşterilerine her bir odasında "modern konfor" olarak adlandırılan daimi sıcak-soğuk su, banyo, tuvalet, telefon ve radyo hizmeti vadetmekteydi. Ayrıca motelin restoranı, benzer müesseselerden alafranga servisi ve Amerikan barıyla ayırt edilmekteydi. Otomobilli müşterilere sunulan bu hizmetlere ek olarak, konaklama tesisinin bünyesinde bir benzin istasyonu mevcuttu. ${ }^{39}$

1950 ve 60'lı yıllarda karşımıza çıkan Emniyet Motel, Florya ve Kilyos Tesisleri bünyesinde yer alan $A$ ve $B$ Moteli, TUSAN Motelleri ve Çizmecioğlu Motel, moteli motel yapan özellikler olan, kent merkezinde değil, karayolu üzerinde bulunma ve bu doğrultuda benzin şirketleriyle kurdukları ortaklıklar ve mekânsal olarak otele kıyasla küçük ölçekleri ve lüks yerine işlevsel ve biçimsel yalınlık sunmaları açılarından ortaklıklar göstermekte ve o dönem için Türkiye'de yer alan motel tipolojisini örneklemektedirler.

\section{Popülerliğini Kaybeden Motel Tipolojisi}

1960 'larda en yüksek düzeye ulaşan motel sayısı, ABD'de daha farklı ve yeni işletmelerin kurulmasıyla

\footnotetext{
${ }^{39}$ Gönlügür, Savaşır ve Ultav, 2016
}

1970'lerden itibaren düşüşe geçmiş; tekil moteller, motel zincirlerinin standartlaşmış işletme modelleriyle yarışamaz hale gelmiştir. ${ }^{40}$ Bu düşüşte, otoyolların, mevcut yol üstü yerleşimlerinin dışına alınmasının payı büyüktür. Karayolu üzerinde konumlanan moteller, turizm konaklama işlevlerini geri plana atarak, konaklayanlara daha çok konfor ve lüks sağlayan işletmeler olmaya başlamıştı. Böylece, 1970 'lerde motellerin çoğu bir zincirin parçası haline gelmiş; zincirler büyüdükçe konumlandıkları yer ile kurdukları ilişki daha homojen ve tanımsız hale gelmeye başlamıştı. ${ }^{41}$ Motel sayısının hızla arttı̆ı 1950'lerden itibaren, geleneksel çekirdek aileler motellerin potansiyel kullanıcıları olarak görülürken, $70^{\prime}$ li yıllardaki küresel ekonomik bunalımın da etkisiyle bu durum dönüşmeye başlamıştr. 1980'lerden sonra iş için seyahat edenlere de hizmet sunma amacl, motellerin müşteri yelpazesinde değişime neden olmuştur. ${ }^{42}$ 1990'larda, Amerika'da özellikle daha eski otoyollar üzerinde konumlanan motellerin kullanımı sona ermiş; terk edilmiş pek çok motel yenilenerek butik otel ya da motel olarak tekrar açılmışttr. ${ }^{43}$ Motel zincirlerinin çoğu, küresel ölçekte görülen liberal ekonominin etkisiyle, büyük işletmeler tarafindan satın alınmaya başlanmıştı. Turizm sektöründe erişilen doygunluk seviyesiyle, klasik moteller ya

\footnotetext{
${ }^{40}$ Elston, 1998, s. 7-8. ${ }^{41}$ Endy, 2000. ${ }^{42}$ Elston, 1998, s. 22. ${ }^{43}$ Endy, 2000.
} 

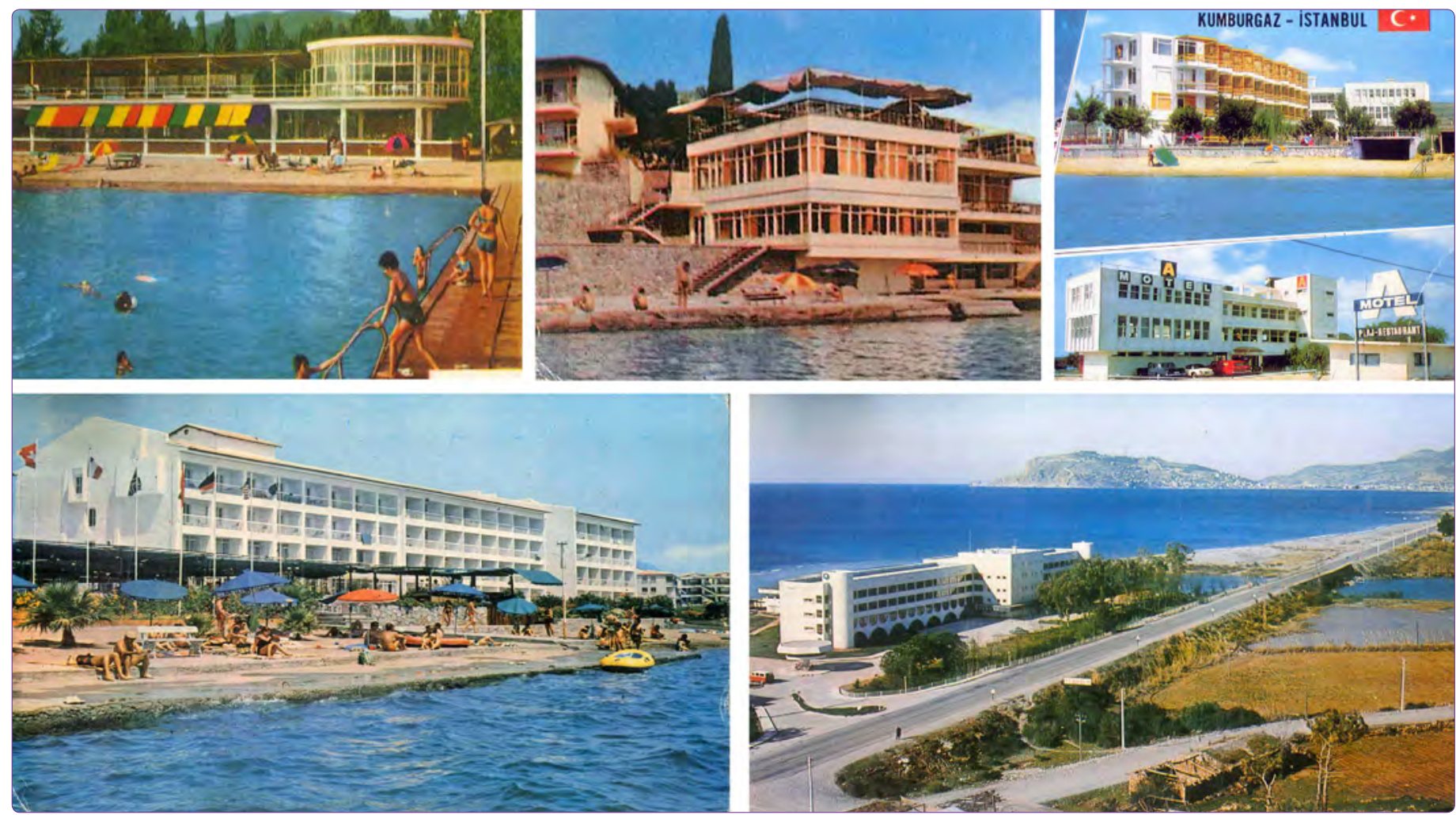

Şekil 15. 1970-90 döneminde Marmara ve Akdeniz kıyılarında motel örnekleri: Yeşim Motel, Erdek; Motel Erdim, İstanbul-Kartal; Motel Kumburgaz, Kumburgaz; Motel Lidya, Marmaris ve Motel Turtel, Side (Yazarların arşivi, 2017).

yıkılmış ya da ikincil yollar üzerine taşınmıştır. ${ }^{44}$ Yüzyıl başında, motellerin Amerikan turizm sektöründeki varlıkları hâlâ sürse de, Avrupa'daki moteller, kullanııılar açısından cazibesini ve bunun sonucunda da turizm alanındaki önemini kaybetmişlerdir. ${ }^{45}$ Günümüzde, karayolu seyahati ve otomobille tatil yapma pratiğinin azalmasıyla, motellerin yerini benzer ölçekli butik oteller ve pansiyonlar almıştır.

Öte yandan, 1970 'lerde Türkiye'de yaşanan siyasi istikrarsızlık ve ekonomik kriz, etkisini turizmde de göstermiş; özel otomobille seyahatte azalma görülmüş; bu düşüş havayolu seyahatinin artışıla daha dramatik boyutlara ulaşarak, motellerin kullanımlarının neredeyse yok denecek kadar aza inmesine neden olmuştur. Özellikle Türkiye turizminde 1980'ler ve 1990'lara gelindiğinde motel tipolojisinin konaklama tesislerinin tercihi sıralamasında listenin başında yer almadığı gerçeği göze çarpmaktadır. Özgüç'ün ifadesiyle moteller “(...) daha çok otele dönüştürüldükleri için, hem sayıca önemli ölçüde azalmışlar hem de yatak kapasiteleri daralmıştı"." 46

\footnotetext{
${ }^{44}$ Ritzenthaler, 2018.

${ }^{45}$ Avustralya ve Yeni Zelanda'da yapılan bir araştırmada, motel kullanıcılarının çoğunluğu, 1960'lar ve $70^{\prime}$ lerin eski motellerini sade tasarımlı, samimi, rahat, eski moda, yorgun görünümlü olarak nitelendirmiştir (Lockyer ve Roberts, 2009, s. 29). The American Hotel-Motel Association'da yapılan
}

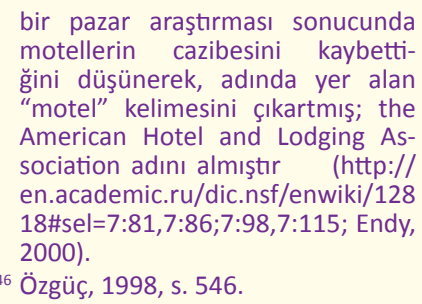
motellerin cazibesini kaybettiğini düşünerek, adında yer alan "motel" kelimesini çıkartmış; the American Hotel and Lodging Association adını almıştır (http:// en.academic.ru/dic.nsf/enwiki/128 18\#sel=7:81,7:86;7:98,7:115; Endy, 2000).

6 Özgüç, 1998, s. 546

Motellerin Türkiye'de gelişen anlamına bakıldı̆̆ında, Amerika'ya paralel gelişmediği görülmektedir. 1960'ları takip eden yıllarda, moteller farklı bir anlam kazanmışlardır. Yerli turizm sektörü büyüdükçe moteller, yeni gelişmekte olan favori tatil kasabalarına gidebilme motivasyonuna sahip ve araba bağımlılığı gittikçe artan bir toplumun uzun yol şoförlerinin durak noktası olarak işlev görmek yerine; orta sınıfin tatil destinasyonlarında konaklama hizmeti sunmak üzere kullanılmaya başlanmıştır. Karayolu üzerinde yer alan bir konaklama tipolojisinden çok; küçük ölçekli ve yalın bir otel tanımına uygun olarak çoğunlukla kıyılarda hizmet verdikleri görülmektedir (Şekil 15).

\section{Değerlendirme ve Sonuç}

1920 lerde Amerika'da ortaya çıkan ve 1950 'lerin ortalarında Avrupa'da ve Türkiye'de de örnekleri görülmeye başlanan moteller, 1960 '। yıllarda Amerikan coğrafyası ${ }^{47}$ dışında daha geri planda kalmıştır ve bu durum, motellerin otoyol peyzajı ve otomobil temelli kentleşme eleştirisin$\mathrm{de}^{48}$ yer almasına neden olmuştur. Daniel J. Boorstin 1965 tarihli yazısında otomobilin, Amerika'nın geniş arazilerinin dönüşümünden ve çoğu Amerikalının yaşama mekânının

\footnotetext{
${ }^{47}$ Amerika'da ayrıca sahil motelle- ${ }^{48} \mathrm{Bk}$. Otoyollar yaşamımıza çarpmışrinin (beach motel) de olduğunu tor ve [bu nedenle] asla aynı olmabelirtmek gerekir. Bk.http://www. yacağız diyen Scott Brown ve Vendigplanet.com/wiki/Motel\#cite_ turi, 1970, s. 9.
} note-depression-young-4. 
tam olarak peyzaj olarak nitelendirilemeyecek -ne kentsel ne de kırsal olan- bir çevreye dönüşmesine neden olduğundan söz ederek; otobanlar, moteller ve müşterilerine arabalarında servis yapan işletmelerin hâkim olduğu Amerikan coğrafyasının büyük çoğunluğunun artkk coğrafi bir peyzaj (landscape) değil, otomobil temelli bir peyzaj (motorscape) olarak tanımlanabileceğini belirtmiştir. ${ }^{49}$

Amerika'da karayolu üzerinde konumlanma özelliğiyle ortaya çıkan motel tipolojisi, özgürleşme, ekonomik refah ve dolayısıyla özel araç kullanımının artş̧ıla turizm sektöründe revaçta olduğu 1970'lerden sonra daha az kullanılır hale gelmiştir. Amerika'da 70'lerden sonra gitgide popülerliğini yitiren motel tipolojisi, her şeye rağmen Amerika'da önemli bir konaklama tipolojisi olarak varlığını sürdürmektedir. Türkiye bağlamında motellerin yerini, bu tipolojiye ölçek olarak yakın olan butik otel ya da pansiyonların almış olduğu görülmektedir. Teknolojik gelişimle yol-araç-zaman arasındaki denklem değişmiş, sürenin azalması seyahat sırasında konaklama ihtiyacını ortadan kaldırmıştır. Bir başka etmenin de, çevrimiçi rezervasyon sistemi nedeniyle, motellerin seyahat sırasında görülerek o anda kalmaya karar verme durumunun sona ermesi olduğu savlanabilir.

1980 sonrasında Türkiye bağlamındaki motel tipolojisinin atıl duruma düşmesini, yıkılıp yok olmasını veya dönüşmesini; mekânsal ekonomik ve sosyo-kültürel olmak üzere üç açıdan ele almak gereklidir. Mekânsal açıdan incelendiğinde, karayollarının niteliksel ve niceliksel olarak gelişmesiyle mesafelerin daha hızlı aşılması ve konaklama intiyacının ortadan kalkması, kara ulaşımından hava ulaşımına kayan tercihler; ekonomik açıdan incelendiğinde, alım gücünün artması, liberal ekonomi ve çoğulculuğun benimsenmesiyle lüks kavramının ortaya çıkması, uluslararası pazara açılma, otellerin kendini farklılaştırma çabaları; sosyo-kültürel açıdan bakıldığında ise tatil anlayışındaki değişim ve yazlık ev kültürünün gelişmesi motel tipolojisinin yok oluş sürecini açıklamaktadır.

Tipoloji; tanımlama, sınıflandırma ve kıyaslama açılarından mimari tipleri anlamak açısından önemli bir araçtır. Bu çerçeveden bakıldığında, konumu ve küçük ölçeği, plan şemalarından da okunabildiği üzere biçimsel ve işlevsel yalınlığı ve sunduğu mekansal konfor anlamında özgün bir tipoloji olarak turizm mimarlığı tarihi ve literatüründe karşımıza çıkan motel tipolojisinin, özgün anlamıyla, kullanıcılarına yeni yaşam biçimi sunduğunu söylemek mümkündür. Ancak, Türkiye'deki örnekler (Emniyet Motel, TURBAN ve TUSAN Motelleri, Çizmecioğlu Motel, Florya ve Kilyos Tesisleri bünyesinde yer alan A ve B Motelleri dışında) bu tanıma uymamaktadır. Bir başka deyişle, aslında bu tipolojinin Türkiye bağlamında özgün anlamıyla uygulandığından söz etmek güçtür. Motel tipolojisi, kıyı turizmine yapılan

\footnotetext{
${ }^{49}$ Aktaran Vieyra, 1995, s. 31.
}

vurguyla, kıyılara yerleşen bir turizm anlayışıyla anlam değiştirmiş, dolayısıyla Türkiye'de yerel yorumunu bulmuştur.

\section{Kaynaklar}

(1961), "Başka Memleketlerde Moteller", Arkitekt, Sayı 303, s. 69.

(1957), "Memleketimiz Modern Bir Motele Kavuştu", Milliyet Gazetesi, 22 Temmuz 1957.

Bandini, M. (1984), "Typology as a Form of Convention", AA Files, Sayı 6, s.73-82.

Čavlović, M. (2018), "Constructing a Travel Landscape: A Case Study of the Sljeme Motels along the Adriatic Highway", Architectural Histories, Cilt 6, Sayı 1, s.1-14.

Clark, D. (1992), "From Oasis to Metropolis: Southern California and the Changing Context of American Leisure", Pacific Historical Review, (Ağustos, 1992), s.361.

Davis, C. (1992), "From Oasis to Metropolis: Southern California and the Changing Context of American Leisure", Pacific Historical Review 61, s.357-368.

Elston, T.J. (1998), “Homogenous Landscape: The American Motel as a Cultural Indicator", Basılmamış Yüksek Lisans Tezi, School of Architecture University of Nevada, Las Vegas.

Endy, C. (2000), "U.S. Tourism in France: An International History, 1944-71", Basılmamış Doktora Tezi, University of North Carolina.

Gönlügür, E. (2014), “Emniyet Motel”, sözlü görüşme, gerçekleştiren Z. Tuna Ultav ve G. Savaşır, İzmir.

Gönlügür, E., Tuna Ultav, Z. ve Savaşır, G. (2016), “Çizmecioğlu (Çizmeci) Motel", DOCOMOMO XII_Türkiye Mimarlı̆̆ında Modernizmin Yerel Açılımları, Ondokuz Mayıs Üniversitesi, Samsun, 16-18 Aralık 2016.

Hurda, Ş. (2010), "TUSAN Motelleri", sözlü görüşme, gerçekleştiren Z. Tuna Ultav ve G. Savaşır, Aydın.

Kopper, C. (2013), "Popular Tourism in Western Europe and the US in the Twentieth Century: A Tale of Different Trajectories", European Review of History: Revue européenne d'histoire, Cilt 20, Sayı 5, s.777-792.

Lazzaretto, C. (2007), "The Bungalow and the Automobile: Arthur and Alfred Heineman and the Invention of the Milestone Motel", Basılmamış Yüksek Lisans Tezi, Faculty of The School of Architecture University of Southern California, California.

Lockyer, T., Roberts, L. (2009), "Motel Accommodation: Trigger Points To Guest Accommodation Selection", International Journal of Contemporary Hospitality Management, Cilt 21, Sayı 1, s.24-37.

Mısırlı, İ. (2001), Konaklama İşletmelerinde Önbüro Teknikleri ve Uygulamaları, Ankara, Detay Yayıncılık.

Nathaus, K. (2013), "The Production of Popular Culture in Twentieth-Century Western Europe: Trends in and Perspectives on 'Europop'", European Review of History: Revue Européenne d'Histoire, Cilt 20, Sayı 5, s.737-754.

Nohutçu, A. (2002), "Development of Tourism Policies in Turkey throughout the Republican Period in Socio-Political, Economic and Administrative Perspective: from State-Sponsored Development to Various Forms of Cooperation", Muğla Üniversitesi Sosyal Bilimler Enstitüsü Dergisi, Sayı 9, s.1-25.

Özgüç, N. (1998), Turizm Coğrafyası: Özellikler ve Bölgeler, İstanbul, Çantay Kitabevi.

Ritzenthaler, G. (2018) "Motels in Michigan. A Brief History of 
the Motel Industry from Its Inception to the Present, http:// www.waterwinterwonderland.com/motels.aspx [Erişim tarihi 18 Ekim 2018].

Roth, M.W. (2000), "Roadside Dreamin' The World's First Motel Opened a New Chapter in California Car Culture", Westways: Southern California's Lifestyle Magazine, Mayıs-Haziran 2000, s.16.

Sağlam, H. (1995), “Cumhuriyet Dönemi Mimarlık Politika İlişkisi: Turizm Konaklama Yapıları Aracılığı ile İrdelenmesi”, Basılmamış Yüksek Lisans Tezi, Fen Bilimleri Enstitüsü, Gazi Üniversitesi, Ankara.

Scott Brown, D., Venturi, R. (1970), "The Highway", The Highway, sergi kataloğu, Philadelphia, Institute of Contemporary Art.

Smithson, A., Smithson, P. (1970), "Mobility", Architectural Design, Cilt 28, Sayı 10, s. 385-86.

Tekeli, İ. (2007), "Türkiye'de Mimarlığın Gelişiminin Toplumsal Bağlamı”, Ed. R. Holod, A. Evin ve S. Özkan (editörler) Modern Türk Mimarlığı 1900-1980, Ankara, TMMOB Mimarlar Odası Yayınları.

Tuna Ultav, Z., Savaşır, G. (2016), 50 Yılın Ardından Türkiye'nin Illk Otel Zinciri TUSAN M/Oteller, İzmir, Yaşar Üniversitesi Yayınları.

Vanlı, Ş. (1994), “Arayış ve Uygulamanın Kırk Yılı: 1950-60 Dö- nemi Kabul Değiştiriyor", Arredamento Mimarlık, Sayı 63, s. 108-113.

Vieyra, D.I. (1995), “The Architecture of America's Roadside Lodging from Its Beginning to the Interstate Era", Basılmamıs Doktora Tezi, Program in American Studies Case Western Reserve University.

\section{Internet Kaynakları}

http://www.waterwinterwonderland.com/motels.aspx [Erişim tarihi 18 Ekim 2018].

http://digitallibrary.usc.edu/cdm/landingpage/collection/ p15799coll59 [Erişim tarihi 15 Ağustos 2018].

http://en.academic.ru/dic.nsf/enwiki/12818\#s el=7:81,7:86;7:98,7:115 [Erişim tarihi 4 Ağustos 2018].

http://tr.emniyetmotel.com/index.html [Erişim tarihi 10 Nisan 2017].

http://www.kwff.org/our-story [Erişim tarihi 4 Ağustos 2018]. http://www.tdk.gov.tr [Erişim tarihi 4 Ağustos 2018].

http://www.digplanet.com/wiki/Motel\#cite_note-depressionyoung-4 [Erişim tarihi 4 Ağustos 2018].

https://www.linktv.org/shows/artbound/checking-in-at-theworlds-first-motel-san-luis-obispos-motel-inn [Erişim tarihi 4 Ağustos 2018] 